\title{
연구논문
}

\section{Perception of the Risk Factors in Official Development Assistance (ODA) Construction Project Management: Focused on Comparison between Project Owner and Construction Manager in KOICA Grant Projects}

\begin{abstract}
This study identified the most critical empirical risk factors at three sequential phases in a preconstruction period and investigated different perceptions of those risk factors by project owners (Korea international cooperation agency officers, KOICA) and construction managers (CM). It was found that the most prioritized empirical risk factors were evenly distributed in the three phases of the preconstruction period. Furthermore, the bidding phase of the Official Development Assistance (ODA) construction project had more high-ranking factors than the other phases; therefore, risk management
\end{abstract}

\footnotetext{
* Managing Director, TOPEC Engineering Co., Ltd. / archihobby@gmail.com

(c) Copyright Korea International Cooperation Agency. This is an Open-Access article distributed under the terms of the Creative Commons Attribution Non-Commercial License (http://creativecommons.org/ licenses/by-nc/4.0/) which permits unrestricted non-commercial use, distribution, and reproduction in any medium, provided the original work is properly cited.
} 


\section{Abstract}

in this phase needs particular attention. This study demonstrated the different perceptions of some risk factors, which are statistically significant, by various practitioners from the project owner (KOICA) and CM, on five factors based on occurrence and severity through a nonparametric test. KOICA placed higher awareness than CM on the nine critical risk factors, which are mostly technical survey and cost estimation related factors except one, which is a procurement-related factor. This study will encourage professional practitioners in KOICA ODA construction project management to enhance their risk management function based on the most critical risk factors and ensure their efficient cooperation.

Key words: Perception of Risk Factors, International Development Cooperation, Construction Management, Korea International Cooperation Agency, ODA Construction Project, Empirical Risk Factors 


\section{I . INTRODUCTION}

Official Development Assistance (ODA or International Development Cooperation) programs including construction projects have played significant roles contributing to the development of least developed countries (LDCs) worldwide. Moreover, there is considerable evidence that ODA projects' fruits are steadily working for a country, even after entering the developed country position. For instance, the National Medical Center of the Republic of Korea is a center of public healthcare taking the lead to improve a preventive healthcare system in the country registered as the 24th member of the OECD/DAC in 2009. This center, which has also worked as a control tower for a disaster like the COVID-19 outbreak, was an ODA program outcome comprising a hospital building construction project established with humanitarian aid from Scandinavian countries (medical support teams from Sweden, Denmark, and Norway) and United Nations Korean Reconstruction Agency (UNKRA) in 1958. During the time, the Korean government needed to rebuild the destroyed medical facilities and nurture modern medical personnel after the Korean War.

On the other hand, most construction projects in ODA programs are likely to be delayed (Ahsan \& Gunawan, 2010; Kaimasu et al., 2016; Otsu et al., 2002) and to exceed initial cost estimates as they are more peculiar than conventional projects for several reasons (Ahsan \& Gunawan, 2010). KOICA (Korea International Cooperation Agency)'s construction projects are no exception. KOICA has been still struggling against occurring of project delay, defects, cost increase, and disputes in her ODA construction projects around the world.

Nevertheless, there is a lack of study on ODA construction project management. This lacking might be caused because the ODA construction project is relatively small and is regarded as just a supporting character for the capacity building program, the ODA program's main objective. Sometimes, there is participants' overlooking the fact that the building facility is one of the critical parts of KOICA ODA program.

This study focused on the comparison between KOICA and construction manager (CM) in their perception of risk factors in KOICA ODA construction project management. The perception of risk is not the risk itself. It changes based upon 
the belief about a risk or a finite probability of an undesirable outcome. Also, it is common sense that each positioned person or group can be different from the other in his/her perception of risk in the same situation due to his/her different involvement and perspective in a project. Therefore each member of one team shall be understanding each other more deeply by sharing each other's perception of the same issues for their better cooperation to achieve the team's objective. KOICA (the project owner) and the CM (construction manager or construction management service provider) are on the same page who should manage the KOICA ODA construction project successfully by mutual coordination and cooperation as the $\mathrm{CM}$ is officially requested to be involved in the whole lifecycle of a construction project as same as the project owner from the initial planning stage to the final evaluation stage (KOICA, 2021). That's why any difference in each group's perception of risk needs to be specified. This can encourage them to reach a mutual decision timely and cooperatively to achieve the best project performance.

This study referred to Oh (2018)'s research which is the first academic approach to outline the empirical risk factors of KOICA ODA construction project management. The researcher reviewed and accepted the empirical factors from Oh's findings to identify the most prioritized risk factors at each different sequential phase in a preconstruction period. The researcher also investigated the different perceptions between key stakeholders who should be one team for the project management, namely KOICA the project owner, and CM. Generally, the CM works to lead a collaborative multi-party team in delivering a high-quality project safely, on time, and within a budget on behalf of the owner (McKeon, 2011). Particularly in the case of KOICA ODA projects, the CM should cooperate more closely with the project owner KOICA from the initial planning phase of the construction projects.

It is novel that this study identified the most critical risk factors at three sequential phases in a preconstruction period of the KOICA ODA construction project and investigated the different perceptions of those risk factors between the practitioners from KOICA and CM. This study will help professional practitioners in ODA construction project management to develop a risk management function based on the most critical risk factors and to ensure efficient coo- 
peration by understanding precisely other stakeholders' different perceptions of the same risk factors.

\section{LITERATURE REVIEW}

\section{KOICA ODA Characteristics: Grants Program Inclusive of Construction Projects}

ODA projects are mainly categorized into three types comprising grants, technical assistance, and loans. This study primarily focused on construction projects in the grant programs. The Korea International Cooperation Agency (KOICA) was established in April 1991 as a government-funded agency dedicated to the Korean government's ODA grant programs.

KOICA has more portion of the construction-related project in its ODA programs than other donor agencies. In 2014, half of the total KOICA ODA programs had included construction projects, and the construction budget was approx. 17\% out of total (Bang, 2014). The construction project still has a significant role in KOICA ODA programs. The construction budget has been increased following the rapid increase of the Korean government's total net ODA (〈Figure 1〉).

〈Figure 1〉 Net ODA provided from the Republic of Korea

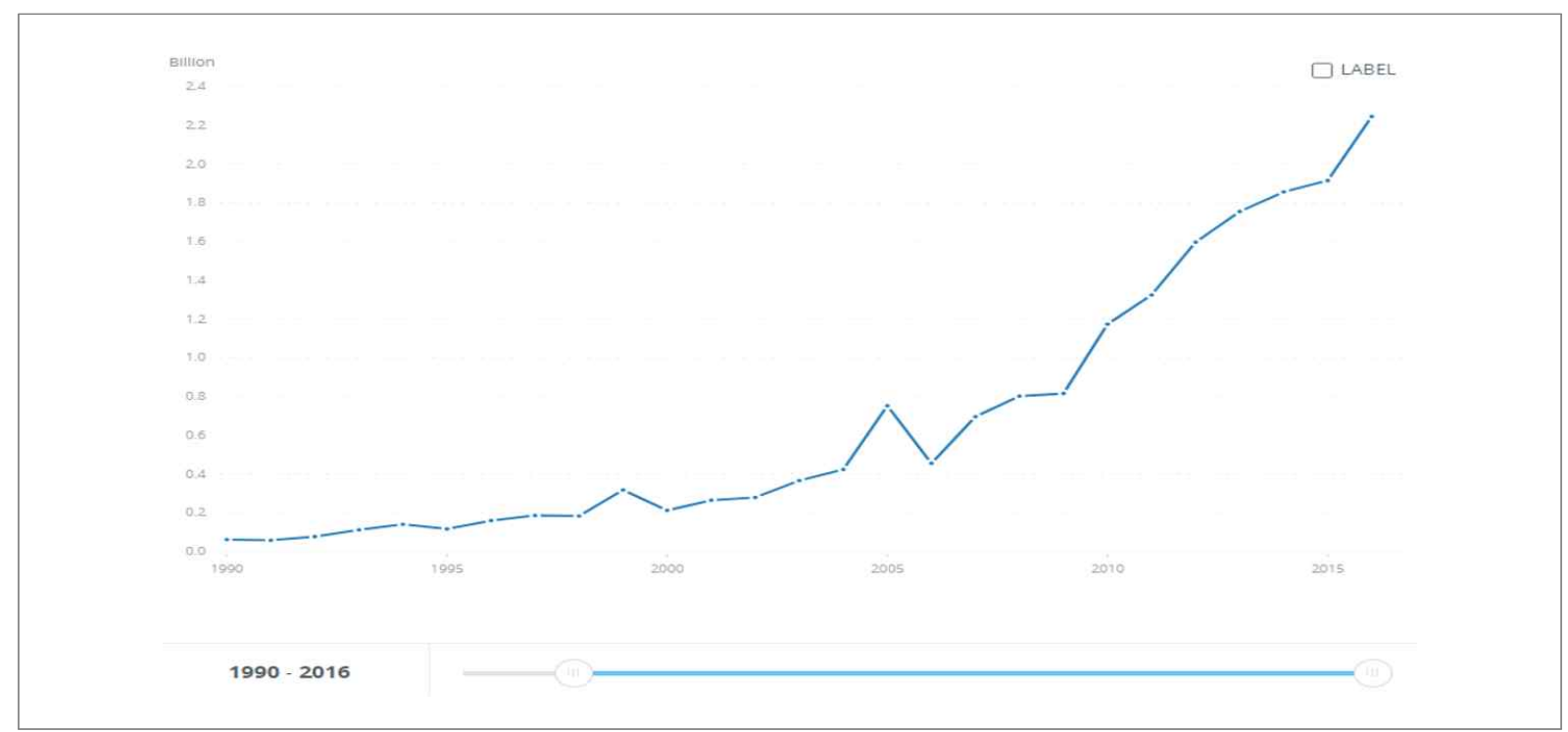

Source: https://oecd.org/dac/stats/idsonline

Note: ODA, Official Development Assistance. 
According to the Ministry of Foreign Affairs Korea (April 2020), Korea's ODA increase rate over the past ten years is $11.9 \%$ /year, which is five times higher than the mean of OECD DAC member countries.

\section{Construction Project's Impact on ODA Program}

ODA construction project usually is a part of an integrated capacity building program. Therefore it should have a specific time bar for completion of the construction works, and the structure completed on time in the estimated schedule is crucial. In case of delay or defects of an ODA construction work, the integral capacity building program's objective and the overall plan would be adversely affected accordingly.

\section{Rare Successful Cases in Terms of Construction Project Ma- nagement}

Unfortunately, completed construction projects within an initially estimated schedule and budget are rare in the KOICA ODA programs. Oh (2018) discovered that only $5 \%$ out of the KOICA project cases were completed within the contract schedule. Japanese ODA construction projects, which have many more cases than Korea's, are also likely to have similar results. Otsu et al. (2002) found through ex-post evaluation reports of the ODA loans, 26 out of 35 projects experienced delays in completion, and 20 projects' costs increased from their initial cost estimates. Kaimasu et al. (2016) also reported that more than $80 \%$ of the Japan ODA loan projects were not completed within the initially scheduled period. These frequent delays are occurred not only in bilateral ODA but also in multilateral ODA as well. ADB's post-project appraisal reports said that project duration was generally longer than estimated (Ahsan \& Gunawan, 2010).

Otsu et al. (2002) concluded that more delays exist in the preparation phase than in the construction phase. Kaimasu et al. (2016) insisted that the leading causes of such delays were generally unpredictable and uncontrollable. 


\section{Risk Management}

According to the Project Management Institute (PMI, 2017), a risk is an uncertain event or condition that, should it occur, has either a positive or negative impact on one or more project objectives. However, generally uncertain events with negative impacts are called risks (Serpell et al., 2014). Furthermore, the risk is a measure of the probability and severity of adverse effects (Aven, 2011; Hubbard, 2009) affecting project objectives (Baloi \& Price, 2003). Today every organization faces uncertain events that occur in different environments and with other characteristics and impacts. These uncertain events can generate more or less severe consequences for the organization (Aven, 2011). The construction industry is no exception in being exposed to these uncertainties, which are complex and diverse risks (Zhao et al., 2013). The management of these risk events to mitigate or eliminate the occurrence and impact of adverse effects and encourage positive results is called Risk Management (Boateng et al., 2020).

Crispim et al. (2019) posited that the inability to cope with risk is the leading cause for exceeding budget, deadlines, and other project objectives. To mitigate or eliminate the risk, we count on risk management, an integral part of project management (Serpell et al., 2014). Risk management is a positive and proactive process intended to reduce the likelihood of harmful consequences to the project in its different stages, such as design, construction, and operation (Mills, 2001; Rohaninejad \& Baherpour, 2013). Judiciously managing risk does not imply avoiding it but identifying it correctly and determine all associated opportunities and hazards (Szymańksi, 2017).

\section{KOICA ODA Construction Projects}

KOICA's ODA Project formation procedure comprising a building construction has multiple steps as 〈Figure 2$\rangle$.

This study focused on empirical risk factors at the preconstruction stage, including 3 phases of planning, design, and bidding. KOICA ODA construction projects have been managed by such cooperative effort between KOICA (as a project owner) \& CM institute (as a CM). Particularly as shown in the $\langle$ Table 1〉, 
〈Figure 2〉 KOICA's ODA project formation procedure

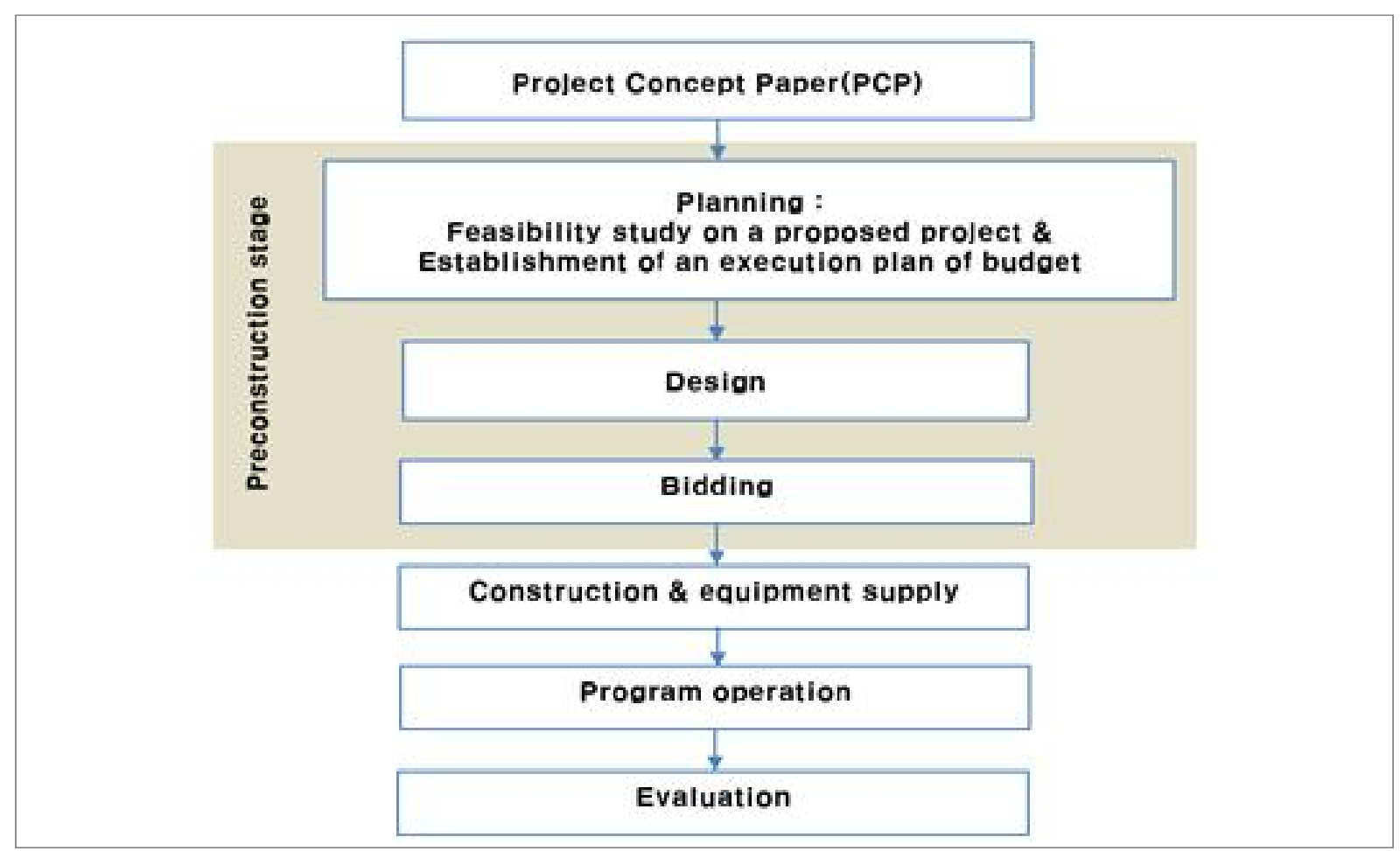

Note: ODA, Official Development Assistance.

$\langle$ Table 1〉 Role undertakings by each participant in KOICA ODA construction project

\begin{tabular}{|c|c|c|c|c|c|c|}
\hline \multirow{3}{*}{ Stage } & \multirow{3}{*}{ Task description } & \multicolumn{5}{|c|}{ Construction project participant } \\
\hline & & \multirow{2}{*}{ KOICA } & \multirow{2}{*}{$\mathrm{CM}$} & \multirow{2}{*}{ PMC } & \multicolumn{2}{|c|}{ Contractor } \\
\hline & & & & & Design & Construction \\
\hline \multirow{9}{*}{$\begin{array}{l}\text { Common } \\
\text { task }\end{array}$} & $\begin{array}{l}\text { Establishment \& execution of the } \\
\text { construction project management plan }\end{array}$ & A & S & - & - & - \\
\hline & Claim management & A & S & C & - & - \\
\hline & Project information management & A & S & C & C & C \\
\hline & Project owner's administration & A\&S & C & $\mathrm{C}$ & $E$ & $E$ \\
\hline & VE / LCC management & A & S & - & C & C \\
\hline & $\begin{array}{l}\text { Contract price adjustment as per } \\
\text { design change/fluctuation }\end{array}$ & A & S & - & $\mathrm{E}$ & E \\
\hline & $\begin{array}{l}\text { Hosting a meeting among the } \\
\text { construction project participants }\end{array}$ & A & S & C & C & C \\
\hline & $\begin{array}{l}\text { Report on the construction project } \\
\text { management }\end{array}$ & A & S & - & C & c \\
\hline & $\begin{array}{l}\text { Other tasks related to construction } \\
\text { project management }\end{array}$ & A & S & - & C & C \\
\hline
\end{tabular}


$\langle$ Table 1〉 Continued

\begin{tabular}{|c|c|c|c|c|c|c|}
\hline \multirow{3}{*}{ Stage } & \multirow{3}{*}{ Task description } & \multicolumn{5}{|c|}{ Construction project participant } \\
\hline & & \multirow{2}{*}{ KOICA } & \multirow{2}{*}{$\mathrm{CM}$} & \multirow{2}{*}{ PMC } & \multicolumn{2}{|c|}{ Contractor } \\
\hline & & & & & Design & Construction \\
\hline \multirow{3}{*}{$\begin{array}{r}\text { Bidding } \\
\text { (design) }\end{array}$} & $\begin{array}{l}\text { Preparation of RFP \& bidding } \\
\text { document for the design work }\end{array}$ & A & S & $\mathrm{C}$ & - & - \\
\hline & Bidding plan establishment & S & $\mathrm{C}$ & $\mathrm{C}$ & - & - \\
\hline & Bidding administration & S & $\mathrm{C}$ & C & - & - \\
\hline \multirow{9}{*}{$\begin{array}{l}\text { Basic } \\
\text { design }\end{array}$} & Project planning & A & S & C & $E$ & - \\
\hline & Project feasibility report review & $A$ & S & $\mathrm{C}$ & C & - \\
\hline & Construction cost analysis \& review & A & S & - & C & - \\
\hline & $\begin{array}{l}\text { Coordination with the government } \\
\text { authorities }\end{array}$ & A & S & $\mathrm{C}$ & C & - \\
\hline & Basic design VE / LCC & A & S & - & C & - \\
\hline & Basic design quality control & A & S & - & $E$ & - \\
\hline & $\begin{array}{l}\text { Reflection of the design review } \\
\text { committee's comments }\end{array}$ & A & S & C & E & - \\
\hline & $\begin{array}{l}\text { Selection of the government } \\
\text { furnished material }\end{array}$ & S & $\mathrm{C}$ & C & - & - \\
\hline & $\begin{array}{l}\text { Administration for every authority } \\
\text { approval related }\end{array}$ & $A \cdot S$ & $\mathrm{C}$ & $\mathrm{C}$ & $E$ & - \\
\hline \multirow{8}{*}{$\begin{array}{l}\text { Working } \\
\text { design }\end{array}$} & $\begin{array}{l}\text { Cost analysis \& construction cost } \\
\text { propriety review }\end{array}$ & A & S & C & $E$ & $E$ \\
\hline & Working design quality control & A & S & - & $E$ & - \\
\hline & $\begin{array}{l}\text { Working design progress } \\
\text { management }\end{array}$ & A & S & C & $E$ & - \\
\hline & $\begin{array}{l}\text { Cross checking all disciplines \& basic } \\
\text { design }\end{array}$ & A & S & C & E & - \\
\hline & $\begin{array}{l}\text { Project delivery \& contract } \\
\text { management }\end{array}$ & $A$ & S & $\mathrm{C}$ & C & - \\
\hline & Execution of the project budget & $A$ & S & $\mathrm{C}$ & $E$ & - \\
\hline & $\begin{array}{l}\text { Reflection of the design review } \\
\text { committee's comments }\end{array}$ & A & S & C & $E$ & - \\
\hline & $\begin{array}{l}\text { Other tasks related to working design } \\
\text { works }\end{array}$ & $\mathrm{R}$ & S & C & $E$ & - \\
\hline
\end{tabular}




\begin{tabular}{|c|c|c|c|c|c|c|}
\hline \multirow{3}{*}{ Stage } & \multirow{3}{*}{ Task description } & \multicolumn{5}{|c|}{ Construction project participant } \\
\hline & & \multirow{2}{*}{ KOICA } & \multirow{2}{*}{$\mathrm{CM}$} & \multirow{2}{*}{ PMC } & \multicolumn{2}{|c|}{ Contractor } \\
\hline & & & & & Design & Construction \\
\hline \multirow{3}{*}{$\begin{array}{l}\text { Bidding } \\
\text { (cons- } \\
\text { truction) }\end{array}$} & $\begin{array}{l}\text { Establishment of the bidding plan \& } \\
\text { preparation of bidding document }\end{array}$ & $\mathrm{R}$ & S & Co & - & - \\
\hline & Bidding administration & $S$ & $\mathrm{C}$ & Co & - & - \\
\hline & Bid conference & S & $\mathrm{C}$ & Co & - & - \\
\hline \multirow{9}{*}{$\begin{array}{l}\text { Const- } \\
\text { ruction }\end{array}$} & $\begin{array}{l}\text { Review on the construction } \\
\text { commencement report }\end{array}$ & A & S & - & - & E \\
\hline & Construction supervision \& evaluation & A & S & - & - & C \\
\hline & Construction VE review & A & S & Co & - & C \\
\hline & Progress payment control & A & S & - & - & $\mathrm{E}$ \\
\hline & Design change management & A & S & Co & - & E \\
\hline & $\begin{array}{l}\text { Main material handling \& quality } \\
\text { control }\end{array}$ & A & S & - & - & E \\
\hline & $\begin{array}{l}\text { Claim analysis \& dispute } \\
\text { management }\end{array}$ & A & S & C & - & E \\
\hline & Completion inspection \& approval & A & S & C & - & $\mathrm{E}$ \\
\hline & As-built dwg review & A & S & C & C & $E$ \\
\hline \multirow{6}{*}{$\begin{array}{c}\text { Comple- } \\
\text { tion\& } \\
\text { main- } \\
\text { tenance }\end{array}$} & Take-over plan establishment & A & $S$ & - & - & E \\
\hline & O\&M system establishment & A & S & - & - & $E$ \\
\hline & $\begin{array}{l}\text { Confirmation on the rectification of } \\
\text { the defects during the final inspection }\end{array}$ & A & S & - & - & E \\
\hline & Safety, security, O\&M manual & A & $S$ & - & - & E \\
\hline & Defects management & A & S & - & - & $\mathrm{E}$ \\
\hline & Final CM report & A & S & - & - & C \\
\hline \multirow{4}{*}{ Others } & $\begin{array}{l}\text { Project evaluation (intermediate, final, } \\
\text { post occupation) assistance }\end{array}$ & A & $S$ & Co & C & C \\
\hline & $\begin{array}{l}\text { Time management plan for each } \\
\text { project }\end{array}$ & A & S & Co & E & E \\
\hline & Monthly report, completion report & A & S & Co & C & C \\
\hline & Other tasks assigned by KOICA & A & $S$ & Co & & C \\
\hline
\end{tabular}

Source: KOICA (2021).

Note: ODA, Official Development Assistance; CM, construction manager; S, Superintendence; A, Approval; C, Cooperation; E, Organizing \& Execution; Co, Consultation; R, Review. 
$\mathrm{CM}$ is officially requested to be involved in the initial planning stage up to the evaluation of the project. Therefore, investigating the two different groups' perceptions of the same risk is strongly necessary for mutual coordination and cooperation in their project management and will enrich risk management literature.

\section{Empirical Risk Factors}

Risk formulation may not be understood without determining the impacting factors that lead to hazardous situations (Alomari et al., 2018). Therefore understanding the root causes of inhibiting issues can reduce uncertainty and provide guidelines for eliminating, substituting, or mitigating the assumed risks. This study referred to Oh (2018) for selecting the thirty-seven (37) empirical risk factors in the KOICA construction project's preconstruction period. To select the risk factors, Oh (2018) reviewed relevant literature and investigated 25 KOICA construction project cases in terms of defects, delay, cost increase, and disputes. Then the outlined risk factors were reviewed and finalized after consultation with professional practitioners who had experienced KOICA projects. The researcher of this study is one of these practitioners who contributed to Oh's findings and still agrees on the risk factors based on his KOICA ODA construction project management experience as both CM and KOICA office inhouse adviser. Therefore, this study accepted the risk factors from Oh's thesis as there has been no particular change in KOICA construction project circumstances since then. All the risk factors were converted into codes which consist of ten (10) factors at the project planning (feasibility \& budget establishment) phase, sixteen (16) factors at the design phase, and eleven (11) factors at the bidding phase as $\langle$ Table 2$\rangle$, 〈Table 3$\rangle$, 〈Table 4$\rangle$. 


\section{〈Table 2〉 Risk factors at planning phase}

Risk factors at planning phase (feasibility study on a proposed project \& establishment of an execution plan of budget)

P01 Inadequate understanding of the recipient country's needs \& demands

P02 Inadequate survey on the prospective project site and improper suggestion on the site selection

P03 Unclearly divided undertakings between KOICA \& recipient country

P04 A mistake in the project schedule estimation

P05 A mistake in the project cost estimation

P06 Inadequate survey on the local construction environment

P07 A mistake in the project size estimation not considering the project budget

P08 Improper space program establishment

P09 Improper design instruction

P10 Improper suggestion on the selection methods of designer, contractor, supervisor, and $\mathrm{CM}$ for the project implementation

Source: Oh (2018).

Note: CM, Construction Manager.

\section{〈Table 3〉 Risk factors at design phase}

Risk factors at design phase

D01 Discordance between project purpose \& design concepts

D02 Inadequate consideration of requests from both KOICA \& recipient country in the design outputs

D03 Lack of reliability in the geological survey data

D04 Design drawings that are different from project site conditions

D05 Structural design \& construction method not considering the local capability

D06 Building size \& finishing materials not considering the project budget

D07 Improper cost estimates

D08 Unclearly specified undertakings \& exclusion out of the contractor's SOW

D09 Inappropriate materials \& equipment not considering the local environment and maintenance

D10 Uncomplying with local codes

D11 Insufficient design of energy-saving \& passive solar system fitting to the local conditions

D12 Exterior design not considering the image of KOICA ODA

D13 Lack of details, omission, mistakes, and ambiguousness of design drawings

D14 Design Specification improper to the local construction works

D15 Omission \& errors in the BOQ

D16 Discrepancies among the design outputs like drawings, BOQs, specifications, etc.

Source: Oh (2018).

Note: ODA, Official Development Assistance. 


\section{〈Table 4〉 Risk factors at bidding phase}

Risk factors at bidding phase

B01 Improper criteria for pre-qualification \& eligibility to bid B02 Inappropriate method to select a preferred bidder

B03 Unclearly defined SOW of the contractor

B04 Period of construction time not considering the local conditions

B05 Incorrect budget estimate published at a bid announcement

B06 Lack of clarification on the delay damage clause

B07 Insufficient explanation on the lump sum price contract

B08 Inapplicable clauses of the disputes and arbitration

B09 Inappropriate clause of the priority of design documents (drawings, specification, BOQ)

B10 Inapplicable clauses of AP bond, P-bond, defects liability bond

B11 Insufficient explanation on the application of VAT \& tax exemption issues (e.g., refund procedure, a party in charge)

Source: Oh (2018).

\section{A Failure Mode, Effects, and Criticality Analysis (FMECA)}

In the late 1940s, the US military was committed to change from an approach of "find failure and fix it" to "anticipate failure and prevent it." The methods developed focused on qualitative and quantitative risk identification for preventing failure. Failure Mode, Effects \& Criticality Analysis (FMECA) is a method that involves quantitative failure analysis (Department of the Army, 2006). The FMECA involves creating a series of linkages between potential failures (Failure Modes), the impact on the mission (Effects), and the causes of the failure (Causes and Mechanisms)(〈Figure 3〉).

Criticality Analysis utilizes Risk Priority Number (RPN; 〈Figure 4〉) for quantifying the level of risks associated with identified failure modes. RPN can be calculated by multiplying the three rankings for severity (How severe are the effects of the failure on the system), occurrence (The likelihood that the failure will occur), and detection (The chance that the failure will be detected) together. The result gives another rank used to prioritize the decisions made to improve the design, process, or system. The RPN ranges from 1 (absolute best) to 1,000 (absolute worst) as all three inputs are ranked on a scale of 1 to 10 . However, RPN in this 


\section{〈Figure 3〉 FMECA}

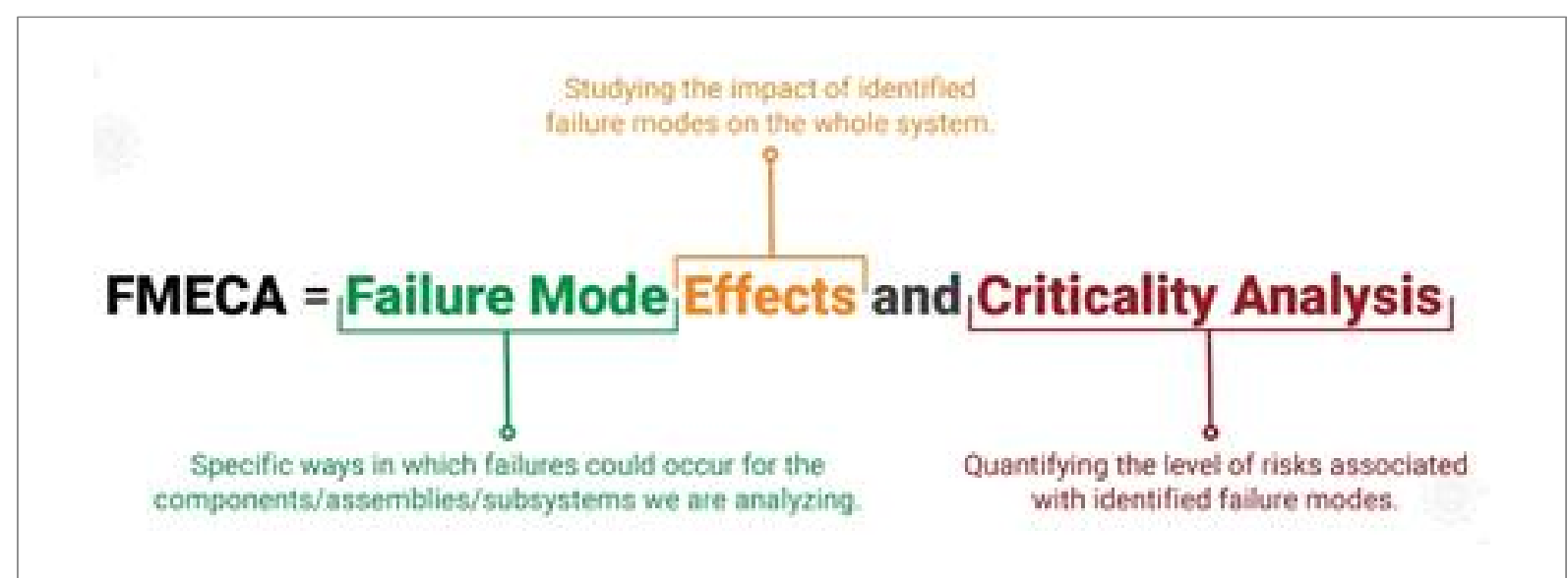

Image Source: limblecmms.com

Note: FMECA, Failure Mode, Effects, and Criticality Analysis.

\section{〈Figure 4〉 Risk priority number}

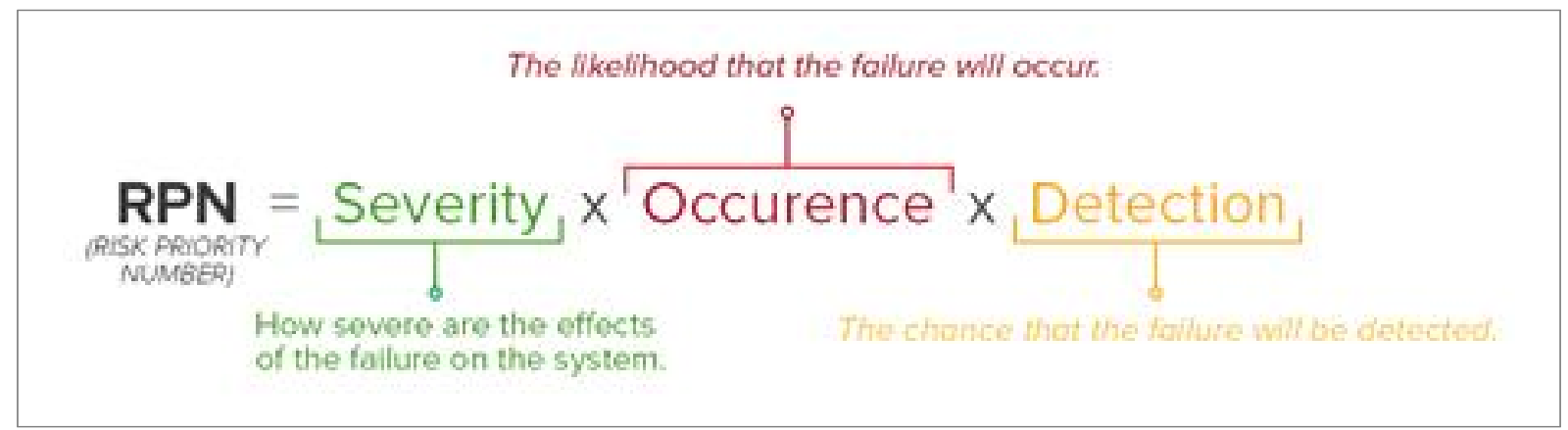

Image Source: http://www.limblecmms.com

study ranges from 1 to 125 due to the use of the 5 point Likert scale.

Many researchers applied FMECA to his/her studies on construction risk management by adjusting the three inputs for RPN calculation to his/her research purpose. Kim (2002) calculated the level of defects (RPN) by multiplying the severity of how severe are the effects of defects on the client (S), the occurrence ratio that the defects will occur (O), and the probability to detect the defects (D). Kim et al. (2012) estimated the exceeding budget risk (RPN) by multiplying the frequency of occurrence $(\mathrm{O})$, expected exceeding amount level when a risk factor occurs (C), and effective level to disrupt the other trade when a risk factor occurs (E). Lee (2011) also adjusted the formula. He achieved RPN to the delay by multiplying impact level of delay and additional cost when the risk factor occurs (S), probability level of risk factor's occurrence (O), and the level 
of impact on the other trades when the risk factor occurs (E). Oh (2018) also applied FMECA to evaluate the Risk factor's priority (RPN) by multiplying the frequency of occurrence (O), Negative impact on the outputs when the risk factor occurs (I), and Probability of critical failure of the project caused by the negative impact of the risk factor (C).

\section{Risk Perception and Research Necessity}

"Risk determination is related to the risk perception process. Risk perception is different from person to person and even among experts as well. In general, people have different perceptions of risk and differ in their evaluation of circumstances, resulting in different interactions in similar situations. As perception is subjective, there may be differences in judgment by different individuals regarding the same risk in the same work environment (Alomari et al., 2018)." A practitioner from each of the positions, either a project owner or a $\mathrm{CM}$, perceives risks from his/her perspective (Alomari et al., 2018). So, both stakeholders always suggest reasonable values of frequency and severity of a risk, which should always be coordinated and determined cooperatively. Regarding KOICA ODA construction project management, the contribution comes from the two key stakeholders, KOICA as a project owner and CM institute as a CM. The project owner possesses decision-making authority during the execution of the project (Olsson, 2018). The CM also holds part of the influence over the project, and the involvement from both stakeholders should remain high during the life cycle of the construction project (Andersen, 2012).

There are also some potential communication challenges between the project owner and the CM (Myrberg, 2020). To obtain the best project performance, collaboration between the project owner and the CM is essential (Turner \& Müller, 2004). However, that is certainly not always the case. Because the project owner has limited time and resources to be highly involved in all projects (Andersen, 2012). So, to increase the likelihood of success, the practitioners from each stakeholder should understand others' perceptions of the project's risk factors and ensure business interaction by emphasizing informed decisions (Crawford et 
al., 2014). However, there has been no study to find the different risk perceptions specifically between the stakeholders. Again, to understand other's perceptions and cooperate efficiently, it is absolutely necessary to know how they differently perceive the same risk factor in the same situation, which makes this study be novel contributing to the risk management literature as a result.

\section{RESEARCH METHODOLOGY}

\section{Questionnaire Survey}

Both methods of qualitative and quantitative approaches were adopted in this study. Data for the research was collected through a literature review and questionnaires survey ( $\langle$ Table 5$\rangle$ ). The empirical data and risk factors at each phase of the preconstruction stage of ODA construction projects were selected through the literature review (Ahsan \& Gunawan, 2010; An \& Song, 2012; Baloi \& Price, 2003; Bang, 2014; Mills, 2001; Oh, 2018). Furthermore, the researcher refined them based on his professional experience. The questionnaire survey was divided into two parts. The first part was on the demographics of res-

\section{〈Table 5〉 Respondents and variables}

\section{Respondents:}

Distribution to: KOICA ODA project experienced pratitioners from KOICA \& CM, n=28 effective responses collected in total

\section{Variables:}

Categorized into 3 phases in a preconstruction period and

Empirical risk factors at each phase, which are inhibiting effective cost and time control of ODA construction project;

Planning phase: 10 risk factors

Design phase: 16 risk factors

Bidding phase: 11 risk factors

Scores on a five-point scaled level (or rankings) of each risk factor (1) very low, (2) low, (3) neutral, (4) high, (5) very high) for three perspectives of 'frequency of occurrence,' 'severity of effects on the project,' and 'probability of detection on the cause.'

Note: ODA, Official Development Assistance; CM, Construction Manager. 
pondents. In this study, respondents were limited to the practitioners who had been involved and experienced KOICA ODA construction projects. In the second part, the questionnaire was made about the empirical risk factors categorized into 3 phases in a preconstruction period; project planning phase, design phase, and bidding phase. The observed risk factors were organized with the main factors inhibiting effective cost and time control of KOICA construction projects at each phase. Ten (10) risk factors at the planning phase, sixteen (16) risk factors at the design phase, and eleven (11) risk factors at the bidding phase were identified (Oh, 2018). 5 point Likert scale was adopted to simplify the ranking score and enable respondents to rank the factors more clearly. Each risk factor was categorized as 'level of frequency of occurrence', 'level of severity of effects on the project', and 'level of probability of detection on the cause of risk' to calculate RPN from the application of FMECA methodology.

\section{Prioritization of Risk Factors by Application of FMECA}

The collected data were analyzed to prioritize risk factors at each phase by applying the FMECA method. Through this analysis, the researcher was able to identify the most critical factors at each phase in the preconstruction period in terms of risk management of ODA construction projects. In this study, to compute the RPN as the risk factor's priority, all ranks from 3 perspectives at each factor were multiplied as 〈Table 6〉.

Accordingly, the RPN score will be ranged from 1 to 75 at the maximum. The researcher can conclude that the risk of the factor with greater RPN would be getting more effective on the project, which could be significantly considered in the risk management of construction projects.

\section{〈Table 6〉 Computation of RPN}

Risk factor's priority (RPN)

$=$ Level of 'frequency of occurrence' $x$ level of 'severity of effects on the project' $x$ level of 'probability of detection on the cause.'

Note: RPN, Risk Priority Number. 


\section{Comparison of Perception between Different Stakeholder Groups by Nonparametric Test (Mann Whitney U test)}

Lastly, the collected data were investigated again to analyze if different stakeholders' perceptions of a risk factor would differ. The researcher performed a nonparametric test (Mann Whitney U test) on the collected data. Because the number of data from each stakeholder group was smaller than 30, which would not be normally distributed. A null hypothesis and an alternative hypothesis were established $\langle$ Table 7$\rangle$ to test if the null hypothesis would be rejected or the test failed to reject it. The test was computed by the operation of SPSS.

\section{DATA ANALYSIS AND FINDINGS}

\section{Respondents' Profile}

Questionnaires were administered via email. Subsequently, twenty-eight (28) valid responses were collected (〈Table 8$\rangle$ ). There were eighteen (18) valid responses from KOICA officers who experienced construction projects from a position as a project owner and ten (10) valid responses from practitioners who had worked as CM from construction management companies for KOICA ODA construction projects.

\section{Questionnaire Reliability}

Cronbach's alpha is a single-administration test score reliability (i.e., the reliability of persons over items holding occasion fixed) coefficient. Also, it is the most famous and commonly used among reliability coefficients. As a rule of

\section{〈Table 7〉 Hypothesis ( $\mathrm{HO}$ and $\mathrm{H} 1$ )}

$\mathrm{HO}$ : There is no different perception of the risk factor between the two stakeholder's groups

$\mathrm{H} 1$ : There is a different perception of the risk factor between the two stakeholder's groups 
〈Table 8〉 Summary of respondents

\begin{tabular}{l|c|c}
\hline \multicolumn{1}{c|}{ Summary of respondents } & Frequency & Percent \\
\hline Profession of respondents & & \\
KOICA Officer (the project owner) & 18 & 64.3 \\
Construction manager (CM) & 10 & 35.7 \\
Project manager (PMC) & - & - \\
Architect & - & - \\
Contractor & - & - \\
\hline Total & 28 & 100.0 \\
\hline Years of experience & & \\
$1-2$ years & 3 & 10.7 \\
$2-4$ years & 12 & 42.8 \\
$4-6$ years & 5 & 17.9 \\
6 years or more & 8 & 28.6 \\
\hline Total & 28 & 100.0 \\
\hline Numbers of KOICA construction & & \\
projects experienced & & \\
$1-3$ & 6 & 21.4 \\
$4-6$ & 5 & 17.9 \\
$7-9$ & 4 & 14.3 \\
10 or more & 13 & 46.4 \\
\hline Total & 28 & 100.0 \\
\hline
\end{tabular}

Note: CM, Construction Manager.

thumb, to satisfy reliability requirements, values should be greater than .7 (Ringle et al., 2020). The most frequently cited source of how much reliability coefficients should be is Nunnally's book (Nunnally \& Bernstein, 1994). .7 is the criterion he recommended for the early stages of a study, and the criterion of .8 referred to applied research by Nunnally is more appropriate for most empirical studies (Lance et al., 2006).

In this study, Cronbach's alpha values ranged between .719 and .848. Thus, the questionnaire satisfied reliability requirements. The 〈Table 9〉 shows the test result on the survey variables in this study.

\section{Risk Priority Analysis}

To prioritize the risk factors in a preconstruction phase of the KOICA ODA 
〈Table 9〉 Test results on the survey variables

\begin{tabular}{c|c|c|c|c|c|c|}
\hline \multirow{2}{*}{ Var.code } & \multicolumn{2}{|c|}{$\begin{array}{c}\text { Level of 'frequency of } \\
\text { occurrence' }\end{array}$} & \multicolumn{2}{|c|}{$\begin{array}{c}\text { Level of 'severity of } \\
\text { effects on the project' }\end{array}$} & \multicolumn{2}{|c|}{$\begin{array}{c}\text { Level of 'probability of } \\
\text { detection on the cause }\end{array}$} \\
\cline { 2 - 8 } & $\mathrm{N}$ & Cronbach's alpha & $\mathrm{N}$ & Cronbach's alpha & $\mathrm{N}$ & Cronbach's alpha \\
\hline P01-P10 & 10 & .845 & 10 & .737 & 10 & .719 \\
\hline D01-D16 & 16 & .848 & 16 & .841 & 16 & .824 \\
\hline B01-B11 & 11 & .820 & 11 & .802 & 11 & .813 \\
\hline
\end{tabular}

construction projects, the researcher calculated the RPN, which is expressed by $\mathrm{RPN}=(\mathrm{OR}) \times(\mathrm{SR}) \times(\mathrm{DR})$ where $\mathrm{OR}$ is the level of frequency of occurrence, SR is the level of severity of effects, and DR is the level of probability of detection. The risk factors with a high RPN are more critical and higher priority than those with a lower RPN.

Out of this RPN analysis as shown in the $\langle$ Table 10〉, the researcher paid attention to the high-ranked risk factors, namely the top 10 risk factors. The result was impressive: most prioritized empirical risk factors were evenly distributed in the three (3) phases of the preconstruction period. The 〈Table 11〉 shows that three (3) factors in the planning phase, three (3) factors in the design phase, and four (4) factors in the bidding phase. It was meaningful that the riskiest factors at each phase in the ODA construction project's preconstruction period were identified. From the result, the bidding phase has more highranking factors than the other phases, which implies that more emphasis needs to be placed on a bidding procedure during risk management of the ODA construction project. Also, half of them have cost estimation-related factors. It shows that risk is most high during the cost estimate activity in a preconstruction period.

The $\langle$ Table 12〉 shows the most prioritized empirical risk factors at each phase in a preconstruction period of ODA construction projects.

\section{Mann-Whitney U Test (Nonparametric Test)}

The Mann-Whitney U test (also called the Mann-Whitney-Wilcoxon [MWW]) is a nonparametric test of the null hypothesis that, for randomly selected values 
〈Table 10〉 Risk priority (RPN) analysis

\begin{tabular}{|c|c|c|c|c|c|c}
\hline Var.code & OR & SR & DR & Criticality $($ OR $\times$ SR $)$ & RPN $($ OR $\times$ SR $\times$ DR) & Rank \\
\hline P01 & 3.04 & 3.75 & 2.64 & 11.40 & 30.10 & 20 \\
\hline P02 & 2.71 & 3.93 & 2.89 & 10.65 & 30.78 & 18 \\
\hline P03 & 3.00 & 3.36 & 2.64 & 10.08 & 26.61 & \\
\hline P04 & 3.86 & 3.43 & 2.61 & 11.52 & 34.56 & 9 \\
\hline P05 & 3.39 & 4.04 & 3.25 & 13.70 & 44.51 & 2 \\
\hline P06 & 3.25 & 3.64 & 2.82 & 11.83 & 33.36 & 12 \\
\hline P07 & 3.25 & 3.64 & 3.00 & 11.83 & 35.49 & 6 \\
\hline P08 & 2.75 & 3.36 & 2.79 & 9.24 & 25.78 & \\
\hline P09 & 2.82 & 3.04 & 2.39 & 8.57 & 20.49 & \\
\hline P10 & 2.61 & 3.54 & 2.96 & 9.24 & 27.35 & \\
\hline D01 & 2.07 & 3.18 & 2.68 & 6.58 & 17.64 & \\
\hline D02 & 2.86 & 3.32 & 2.75 & 9.50 & 26.11 & \\
\hline D03 & 3.00 & 3.61 & 2.93 & 10.83 & 31.73 & 16 \\
\hline D04 & 2.86 & 3.86 & 3.14 & 11.04 & 34.66 & 8 \\
\hline D05 & 2.79 & 3.82 & 3.07 & 10.66 & 32.72 & 14 \\
\hline D06 & 2.93 & 3.61 & 2.71 & 10.58 & 28.66 & \\
\hline D07 & 3.25 & 3.89 & 3.21 & 12.64 & 40.58 & 4 \\
\hline D08 & 2.82 & 3.46 & 2.82 & 9.76 & 27.52 & \\
\hline D09 & 2.86 & 3.61 & 2.96 & 10.32 & 30.56 & 19 \\
\hline D10 & 2.50 & 3.32 & 2.57 & 8.30 & 21.33 & \\
\hline D11 & 2.71 & 2.43 & 1.96 & 6.59 & 12.91 & \\
\hline D12 & 2.43 & 2.36 & 1.96 & 5.73 & 11.24 & \\
\hline D13 & 3.46 & 3.46 & 2.71 & 11.87 & 32.44 & 15 \\
\hline D14 & 3.46 & 3.43 & 2.61 & 11.87 & 30.97 & 17 \\
\hline D15 & 3.50 & 3.64 & 2.68 & 12.74 & 34.14 & 10 \\
\hline D16 & 3.21 & 3.54 & 2.89 & 11.36 & 32.84 & 13 \\
\hline B01 & 2.61 & 4.04 & 3.36 & 10.54 & 35.43 & 7 \\
\hline B02 & 3.14 & 4.04 & 3.54 & 12.69 & 44.91 & 1 \\
\hline B03 & 2.79 & 3.71 & 3.00 & 10.35 & 31.05 & \\
\hline B04 & 3.64 & 3.79 & 3.00 & 13.80 & 41.39 & 3 \\
\hline B05 & 3.11 & 3.79 & 3.07 & 11.79 & 36.19 & 5 \\
\hline B06 & 2.14 & 3.14 & 2.57 & 6.72 & 17.30 & \\
\hline B07 & 3.00 & 3.68 & 3.04 & 11.04 & 33.56 & 11 \\
\hline B08 & 2.36 & 2.86 & 2.25 & 6.75 & 15.19 & \\
\hline B09 & 2.75 & 3.21 & 2.50 & 8.67 & 16.69 & \\
\hline B10 & 2.43 & 2.96 & 2.32 & 7.19 & & \\
\hline B11 & 2.61 & 3.14 & 2.39 & 8.20 & & \\
\hline & & & & & & \\
\hline
\end{tabular}


〈Table 11〉 High-ranked risk factors

\begin{tabular}{c|c|c|c|c|c|c}
\hline Var.code & OR & SR & DR & Criticality & RPN & Rank \\
\hline P04 & 3.86 & 3.43 & 2.61 & 11.52 & 34.56 & 9 \\
\hline P05 & 3.39 & 4.04 & 3.25 & 13.70 & 44.51 & 2 \\
\hline P07 & 3.25 & 3.64 & 3.00 & 11.83 & 35.49 & 6 \\
\hline D04 & 2.86 & 3.86 & 3.14 & 11.04 & 34.66 & 8 \\
\hline D07 & 3.25 & 3.89 & 3.21 & 12.64 & 40.58 & 4 \\
\hline D15 & 3.50 & 3.64 & 2.68 & 12.74 & 34.14 & 10 \\
\hline B01 & 2.61 & 4.04 & 3.36 & 10.54 & 35.43 & 7 \\
\hline B02 & 3.14 & 4.04 & 3.54 & 12.69 & 44.91 & 1 \\
\hline B04 & 3.64 & 3.79 & 3.00 & 13.80 & 41.39 & 3 \\
\hline B05 & 3.11 & 3.79 & 3.07 & 11.79 & 36.19 & 5 \\
\hline
\end{tabular}

Note: RPN, Risk Priority Number.

\section{〈Table 12〉 Top 10 risk factors}

\begin{tabular}{c|l}
\hline Var.code & \\
\hline P04 & A mistake in the project schedule estimation \\
\hline P05 & A mistake in the project cost estimation \\
\hline P07 & A mistake in the project size estimation not considering the project budget \\
\hline D04 & Design drawings that are different from project site conditions \\
\hline D07 & Improper cost estimates \\
\hline D15 & Omission \& errors in the BOQ \\
\hline B01 & Improper criteria for pre-qualification \& eligibility to bid \\
\hline B02 & Inappropriate method to select a preferred bidder \\
\hline B04 & Period of construction time not considering the local conditions \\
\hline B05 & An incorrect budget estimate published at a bid announcement \\
\hline
\end{tabular}

$\mathrm{X}$ and $\mathrm{Y}$ from two populations, the probability of $\mathrm{X}$ being greater than $\mathrm{Y}$ is equal to the probability of $\mathrm{Y}$ being greater than $\mathrm{X}$.

The Mann-Whitney $U$ test tests a null hypothesis that the probability that a randomly drawn observation from one group is larger than a randomly drawn observation from the other is equal to 0.5 against an alternative that this probability is not 0.5 . In contrast, a t-test tests a null hypothesis of equal means in two groups against an alternative of unequal means. Hence, except in special cases, the Mann-Whitney $U$ test and the t-test do not test the same hypotheses. 
The number of data collected from each stakeholder group was less than 30, which means that we cannot assure the normal distribution of data collected from this study survey. Accordingly, the Mann-Whitney $U$ test was performed to compare the two stakeholder groups' perceptions, KOICA staff as a project owner and practitioners from consulting companies as a CM.

The test result showed perception differences, which are statistically significant with a confidence level of 95\%, between project owner and CM on five (5) factors from each perspective of occurrence and severity as shown at the 〈Table 13〉

\section{〈Table 13〉 Perception difference on the empirical risk factors}

\begin{tabular}{|c|c|c|c|c|c|c|c|c|}
\hline \multirow{3}{*}{ Var.code } & \multicolumn{4}{|c|}{ Level of frequency of occurrence } & \multicolumn{4}{|c|}{$\begin{array}{l}\text { Level of severity of effects } \\
\text { on the project }\end{array}$} \\
\hline & \multicolumn{2}{|c|}{$\begin{array}{l}\text { Mean of } \\
\text { responses from }\end{array}$} & \multirow{2}{*}{$\begin{array}{l}\text { Mann } \\
\text { Whitney } \\
\text { U test }\end{array}$} & \multirow{2}{*}{$\begin{array}{l}\text { Cron- } \\
\text { bach's } \\
\text { alpha }\end{array}$} & \multicolumn{2}{|c|}{$\begin{array}{l}\text { Mean of } \\
\text { responses from }\end{array}$} & \multirow{2}{*}{$\begin{array}{c}\text { Mann } \\
\text { Whitney } \\
\text { U test }\end{array}$} & \multirow{2}{*}{$\begin{array}{l}\text { Cron- } \\
\text { bach's } \\
\text { alpha }\end{array}$} \\
\hline & $\begin{array}{l}\text { Owner } \\
\text { (KOICA) }\end{array}$ & $\mathrm{CM}$ & & & $\begin{array}{l}\text { Owner } \\
\text { (KOICA) }\end{array}$ & $\mathrm{CM}$ & & \\
\hline P01 & 3.33 & 2.50 & .064 & .845 & 4.17 & 3.00 & $.006^{* *}$ & .737 \\
\hline P02 & 3.00 & 2.20 & $.024^{*}$ & & 4.17 & 3.50 & .051 & \\
\hline P06 & 3.61 & 2.60 & $.009^{* *}$ & & 3.89 & 3.20 & .057 & \\
\hline D07 & 3.39 & 3.00 & .245 & .848 & 4.17 & 3.40 & $.016^{*}$ & .841 \\
\hline D08 & 3.11 & 2.30 & $.035^{*}$ & & 3.33 & 3.70 & .226 & \\
\hline B02 & 2.78 & 3.80 & $.031^{*}$ & .820 & 3.67 & 4.70 & $.004^{* *}$ & .802 \\
\hline B05 & 3.44 & 2.50 & $.018^{*}$ & & 4.06 & 3.30 & $.045^{*}$ & \\
\hline B09 & 2.94 & 2.40 & .265 & & 3.50 & 2.70 & $.027^{*}$ & \\
\hline \multicolumn{9}{|l|}{ Var.code } \\
\hline P01 & \multicolumn{8}{|c|}{ Inadequate understanding of the recipient country's needs \& demands } \\
\hline P02 & \multicolumn{8}{|c|}{$\begin{array}{l}\text { Inadequate survey on the prospective project site and improper suggestion } \\
\text { on the site selection }\end{array}$} \\
\hline P06 & \multicolumn{8}{|c|}{ Inadequate survey on the local construction environment } \\
\hline D07 & \multicolumn{8}{|c|}{ Improper cost estimates } \\
\hline D08 & \multicolumn{8}{|c|}{ Unclearly specified undertakings \& exclusion out of } \\
\hline B02 & \multicolumn{8}{|c|}{ Inappropriate method to select a preferred bidder } \\
\hline B05 & \multicolumn{8}{|c|}{ An incorrect budget estimate published at a bid announcement } \\
\hline B09 & \multicolumn{8}{|c|}{$\begin{array}{l}\text { An inappropriate clause of the priority of design documents (drawings, } \\
\text { specification, BOQ) }\end{array}$} \\
\hline
\end{tabular}


below. The researcher noticed three (3) risk factors out of five (5) in the severity perspective were from a bidding phase. The project owner ranked more weight than CM on all risk factors except only B02: Inappropriate method to select a preferred bidder which $\mathrm{CM}$ gave much more weight than the project owner.

\section{DISCUSSION}

This study tried to identify prioritized empirical risk factors in a preconstruction period of an ODA construction project. The researcher also investigated the difference in the perception of those empirical risk factors between practitioners from two stakeholder groups KOICA and the CM. And the study result shows that KOICA has a higher awareness of the critical risk factors, except the "B02 Inappropriate Method to Select a Preferred Bidder" alone, than CM has. Most of the critical risk factors which KOICA is aware of higher than CM are relevant to technical survey and cost estimation works. This implies that the project owner KOICA respects the CM to take more care of those factors in the management and $\mathrm{CM}$ needs to develop further measures and interaction with KOICA to mitigate those critical risks in its project management practice. And the only risk factor that the CM gave higher awareness than KOICA, the "B02 Inappropriate Method to Select a Preferred Bidder", shows that the project owner may neglect it because the risk factor is controlled under the government regulation which is beyond the KOICA practitioners' obligation at the level of project management. On the other hand, the practitioners from CM institute who should be more familiar with the overseas project circumstance and international practice than the KOICA officers perceive this factor as a high-risk factor. This implies that the relevant regulation being applied to the KOICA ODA construction procurement needs to be reviewed actively by KOICA and to be improved if necessary. As a result, this study presents some specific risk factors which will help the two stakeholder groups understand each other for better communication and collaboration to achieve the best project performance.

However, this study has some limitations that should be improved later on.

Firstly, the number of data per stakeholder group was limited, less than 30, and could not be distributed normally. That's why the researcher applied a 
nonparametric test (Mann Whitney $\mathrm{U}$ test) in this study but, to improve the research reliability, it is generally recommended to secure survey data more than thirty (30).

Secondly, the survey analysis needs to provide a structural difference of perception by different criteria for further understanding the reason and applying the result more specifically in practice. Also, a follow-up survey on the critical risk factors is necessary to depict more specific perception differences between the groups. This study can be regarded as a first step to investigate the stakeholder's perception of the risk in KOICA ODA construction project management. The supplementary analysis and survey mentioned herein above should be conducted in a succeeding study.

Thirdly, more increased valid data collection and inclusion of all key stakeholders from the ODA construction projects are necessary to enhance this research objective. Studying the same risk factors with various stakeholders and comparing their risk perceptions will give us a better picture of how the key stakeholders in the ODA construction industry perceive the same risk.

Lastly, the research basin also needs to be enlarged to include not only KOICA ODA grant projects but also all ODA grant or loan projects from various donors. Identifying prioritized empirical risk factors and a deep understanding of the different perceptions on the risk factors among stakeholders can greatly contribute to the improvement of risk management in the ODA construction projects.

\section{CONCLUSION}

The findings from this study showed a specific difference between the project owner and the CM in their perception of the risk factors in KOICA ODA construction project management. This will help the practitioners from each stakeholder to understand other's perceptions of the project's risk factors and to ensure active interaction to achieve the best project performance. Also, this can encourage each stakeholder to develop its measure in risk management.

Briefly saying, according to the researcher's implication from the findings in this study, the CM (construction manager or construction management service provider) needs to enhance technical measure and to communicate more closely 
with the project owner KOICA during its project management activity for technical survey related and cost estimation related works. On the other hand, the project owner KOICA needs to review the procurement regulation precisely in consultation with CM (or overseas project procurement specialists) and to try actively to improve it accordingly.

More enlarged investigation on both key stakeholders and empirical risk factors will allow us to deepen risk management on the ODA construction project, leading to ODA programs' success, contributing to socio-economic development and sustainable development of the world.

\section{REFERENCES}

Ahsan, K., \& Gunawan, I. (2010). Analysis of cost and schedule performance of international development projects. International Journal of Project Management, 28(1), 68-78.

Alomari, K. A., Gambatese, J. A., \& Tymvios, N. (2018). Risk perception comparison among construction safety professionals: Delphi perspective. Journal of Construction Engineering and Management, 144(12), 04018107.

An, S. J., \& Song, S. H. (2012). Integrated safety risk assessment and response preparation on construction site formwork using FMECA method. Journal of the Korea Safety Management \& Science, 14(3), 39-48.

Andersen, E. S. (2012). Illuminating the role of the project owner. International Journal of Managing Projects in Business, 5(1), 67-85.

Aven, T. (2011). On the new ISO guide on risk management terminology. Reliability Engineering \& System Safety, 96(7), 719-726.

Baloi, D., \& Price, A. D. F. (2003). Modelling global risk factors affecting construction cost performance. International Journal of Project Management, 21(4), 261-269.

Bang, S. A. (2014). ODA and KOICA construction projects. Korean Journal of Construction Engineering and Management, 15(4), 33-35.

Boateng, A., Ameyaw, C., \& Mensah, S. (2020). Assessment of systematic risk management practices on building construction projects in Ghana. International Journal of Construction Management, 1-9. 
Crawford, L., Aitken, A., \& Hassner-Nahmias, A. (2014). Project management and organizational change. Newtown Square, PA: Project Management Institute.

Crispim, J., Silva, L. H., \& Rego, N. (2019). Project risk management practices: The organizational maturity influence. International Journal of Managing Projects in Business, 12(1), 187-210.

Department of the Army. (2006). TM 5-698-4, failure modes, effects and criticality analyses (FMECA) for command, control, communications, computer, intelligence, surveillance, and reconnaissance (C4ISR) facilities (Technical Manual No. 5698-4). Washington, DC: Department of the Army.

Hubbard, D. W. (2009). The failure of risk management: Why it's broken and how to fix it. Hoboken, NJ: John Wiley \& Sons.

Kim, Y. S. (2002). Approach to method of process failure mode and effect analysis for construction industry. In Proceedings of the Korean Institute of Construction Engineering and Management. Seoul, Korea.

Kim, B. Y., \& Kim, Y. S. (2012). The analysis of the major cost-increasing risk factors from the perspective of construction management: Focusing on pre-construction phases. Korean Journal of Construction Engineering and Management, 13(2), 147-155.

KOICA. $(2021,4,9)$. Task description for the construction management service in Southeast Asia. Retrieved from http://ebid.koica.go.kr

Lance, C. E., Butts, M. M., \& Michels, L. C. (2006). The sources of four commonly reported cutoff criteria: What did they really say? Organizational Research Methods, (2), 202-220.

Lee, S. (2011). Analysis on the factors about the delay of the railway station project using the FMEA method (Unpublished Master's thesis). Hanyang University, Seoul, Korea.

Myrberg, M. E. (2020). The communication process between a project owner and a project manager: A multiple case study of three projects in the construction industry (Master's thesis). BI Norwegian Business School, Oslo, Norway.

Kaimasu, M., Ao, H., Taira, Y., Ogata, M., Kono, Y., Kanematsu, Y., \& Mizukami, T. (2016). Management of ID projects: risk analysis and lessons learned. In Proceedings of 10th International Conference on Project management (pp. 951-956). Gold Coast, Australia. 
McKeon, J. J. (2011). Becoming a construction manager. Hoboken, NJ: John Wiley \& Sons.

Mills, A. (2001). A systematic approach to risk management for construction. Structural Survey, 195), 245-252.

Nunnally, J. C., \& Bernstein, I. H. (1994). Psychometric theory (3rd ed.). New York, NY: McGraw-Hill.

Oh, C. (2018). Development of quantitative evaluation method for the phased performance of KOICA overseas construction projects (Unpublished Master's thesis). University of Seoul, Seoul, Korea.

Olsson, N. O. E. (2018). Elaborations on the role of project owner: Introducing project owners type 1 and 2. International Journal of Managing Projects in Business, 11(3), 827-844.

Otsu, H., Onoi, Y., Onishi, Y., \& Takahashi, T. (2002). A study on risk analysis and responses in ODA construction projects. In Proceedings of the Japan Society of Civil Engineering (No. 714, pp. 155-164).

PMI [Project Management Institute]. (2017). A guide to the project management body of knowledge (6th ed). Newtown Square, PA: PMI.

Ringle, C. M., Sarstedt, M., Mitchell, R., \& Gudergan, S. P. (2020). Partial least squares structural equation modeling in HRM research. The International Journal of Human Resource Management, 31(12), 1617-1643.

Rohaninejad, M., \& Bagherpour, M. (2013). Application of risk analysis within value management: A case study in DAM engineering. Journal of Civil Engineering and Management, 19(3), 364-374.

Serpell, A., Ferrada, X., Rubio, L., \& Arauzo, S. (2014). Evaluating risk management practices in construction organizations. In Conference Proceedings 28th IPMA World Congress. Rotterdam, Netherlands.

Szymańksi, P. (2017). Risk management in construction projects. Paper presented at the 2nd International Joint Conference on Innovative Solutions in Construction Engineering and Management, ORSDCE, Poznan, Poland.

Turner, J. R., \& Müller, R. (2004). Communication and co-operation on projects between the project owner as principal and the project manager as agent. European Management Journal, 22(3), 327-336. 
Zhao, X., Hwang, B. G., \& Low, S. P. (2013). Developing fuzzy enterprise risk management maturity model for construction firms. Journal of Construction Engineering and Management, 13999), 1179-1189.

논문 접수일: 2021.5.17. 수정논문 접수일: 2021.6.14.

게재 확정일: 2021.6.25. 